\title{
A grassed waterway and earthen dams to control muddy floods from a cultivated catchment of the Belgian loess belt
}

\author{
Olivier Evrard $^{\mathrm{a} \diamond^{*}}$, Karel Vandaele ${ }^{\mathrm{b}}$, Bas van Wesemael ${ }^{\mathrm{a}}$, Charles L. Bielders ${ }^{\mathrm{c}}$ \\ ${ }^{a}$ Département de Géographie, Université catholique de Louvain, Place Louis Pasteur, 3, \\ B-1348 Louvain-la-Neuve, Belgium \\ ${ }^{b}$ Watering van Sint-Truiden, Interbestuurlijke samenwerking Land en Water, Minderbroedersstraat, \\ 16, B-3800 Sint-Truiden, Belgium \\ ${ }^{c}$ Département des Sciences du Milieu et de l'Aménagement du Territoire, Université catholique de \\ Louvain, Croix du Sud, 2, Bte 2, B-1348 Louvain-la-Neuve, Belgium \\ ${ }^{\ominus}$ Fonds pour la formation à la Recherche dans l'Industrie et l'Agriculture (F.R.I.A.), Belgium \\ *Corresponding author.E-mail address : olivier.evrard@uclouvain.be (O.Evrard).
}

\begin{abstract}
Muddy floods, i.e. runoff from cultivated areas carrying large quantities of soil, are frequent and widespread in the European loess belt. They are mainly generated in dry zero-order valleys and are nowadays considered as the most likely process transferring material eroded from cultivated hillslopes during the Holocene to the flood plain. The huge costs of muddy flood damages justify the urgent installation of control measures. In the framework of the 'Soil Erosion Decree' of the Belgian Flemish region, a 12 ha-grassed waterway and three earthen dams have been installed between 2002-2004 in the thalweg of a 300-ha cultivated dry valley in the Belgian loess belt. The measures served their purpose by preventing any muddy flood in the downstream village, despite the occurrence of several extreme rainfall events (with a maximum return period of 150 years). The catchment has been intensively monitored from 2005-2007 and 39 runoff events were recorded in that period. Peak discharge (per ha) was reduced by $69 \%$ between the upstream and the downstream extremities of the grassed waterway (GWW). Furthermore, runoff was buffered for 5-12 hours behind the dams, and the lag time at the outlet of the catchment was thereby increased by $75 \%$. Reinfiltration was also observed within the waterway, runoff coefficients decreasing by a mean of $50 \%$ between both extremities of the GWW. Sediment discharge was also reduced by $93 \%$ between the GWW's inflow and the outlet. Before the installation of the control measures, specific sediment yield (SSY) of the catchment reached $3.5 \mathrm{tha}^{-1} \mathrm{yr}^{-1}$ and an ephemeral gully was observed nearly each year in the catchment. Since the control measures have been installed, no (ephemeral) gully has developed and the SSY of the catchment dropped to a mean of $0.5 \mathrm{t} \mathrm{ha}^{-1} \mathrm{yr}^{-1}$. Hence, sediment transfer from the cultivated dry valley to the alluvial plain should dramatically decrease. Total cost of the control measures that are built for a 20 year-period is very low $\left(126 € \mathrm{ha}^{-1}\right)$ compared to the mean damage cost associated with muddy
\end{abstract}


floods in the study area $\left(54 € \mathrm{ha}^{-1} \mathrm{yr}^{-1}\right)$. Similar measures should therefore be installed to protect other flooded villages of the Belgian loess belt and comparable environments.

Keywords : muddy floods; grassed waterway; earthen dams; runoff control; sediment delivery; cost-efficiency.

\section{Introduction}

Muddy floods consist of water flowing from agricultural fields carrying large quantities of soil as suspended sediment or bedload (Boardman et al., 2006). They are therefore considered as a fluvial process rather than a mass movement one. Even though they are frequent and widespread in the European loess belt, they are mainly reported from central Belgium (Verstraeten and Poesen, 1999; Evrard et al., 2007a), northern France (Souchère et al., 2003) and southern England (Boardman et al., 2003). Muddy floods cause numerous offsite impacts, such as flooding of property, sedimentation and eutrophication in watercourses.

About $90 \%$ of muddy floods observed in the Belgian loess belt are generated on cultivated hillslopes (10-30 ha) and in dry zero-order valleys (30-300 ha; Evrard et al., 2007a). Numerous studies carried out in cultivated catchments of the European loess belt showed that most sediments produced during the Holocene have been stored in the dry valley bottom near the catchment outlet and have not been delivered to downstream rivers (e.g. Bork et al., 1998; Lang et al., 2003; Rommens et al., 2005; de Moor and Verstraeten, in press). Rommens et al. (2006) also estimated the Holocene alluvial sediment storage in a small (52 $\mathrm{km}^{2}$ ) river catchment of the Belgian loess belt. They showed that sediment supply towards the alluvial plain has increased dramatically since Medieval times compared to the rest of the Holocene period and occurred at a mean rate of $1.3 \mathrm{t} \mathrm{ha}^{-1} \mathrm{yr}^{-1}$. Since $50 \%$ of sediment eroded from hillslopes was stored in colluvial deposits, mainly located in dry zero-order valley bottoms, muddy floods caused by severe erosion on agricultural land are the mostly likely process transporting sediments from the dry valleys to the alluvial plains. During heavy rainfall in late spring and summer, ephemeral gullies form in these dry valleys. These shallow $(\sim 0.1 \mathrm{~m})$ but wide $(\sim 3 \mathrm{~m})$ gullies act as an important conveyor of sediment and may aggravate the off-site damage produced by muddy floods (Nachtergaele and Poesen, 2002; Verstraeten et al., 2006).

The huge costs associated to this damage, which appears to have occured more frequently during the last decade, justifies the urgent installation of mitigation measures (Evrard et al., 2007a). Two types of measures can be carried out to control muddy floods. On 
the one hand, alternative farming practices implemented at the field scale, such as sowing of cover crops during the intercropping period, reduced tillage or double sowing in zones of concentrated flow, limit runoff generation and erosion production (Gyssels et al., 2002; Leys et al., in press). However, the implementation of these practices directly depends on the farmer's willingness. Except for sowing of cover crops (e.g. in Belgium; Bielders et al., 2003), the adoption of such practices remains rather limited in Europe (Holland, 2004). It will probably still take several years or even decades before reduced tillage and double sowing are applied generally. On the other hand, 'curative' measures aim to reinfiltrate or buffer runoff once it is formed, as well as to trap sediments and pollutants. Typically, grass buffer strips, grassed waterways (GWW) and detention ponds (retaining runoff for a certain time behind a small dam) serve this purpose (Fiener and Auerswald, 2005). Such curative measures are most effective when they are implemented in the framework of integrated catchment management. Hence, a local water board should be responsible for deciding in consultation with farmers where to install these measures within the catchment and for ensuring their maintenance. From 2001 onwards, municipalities in the Belgian Flemish region are eligible for subsidies to draw up an erosion mitigation scheme (Verstraeten et al., 2003). Several smallscale measures such as dams and GWW are being installed in the field but there is a need to evaluate their efficiency before generalising their installation in problem areas. Furthermore, since muddy floods are generated on large surfaces (10-300 ha; Evrard et al., 2007a), the effect of control measures should be investigated at similar scales. However, previous research has focused on the effect of grass buffer strips and has mostly been carried out on experimental plots (typically $500 \mathrm{~m}^{2}$, see e.g. Van Dijk et al., 1996; Patty et al., 1997; Le Bissonnais et al., 2004). With respect to the effect of GWW in the European context, it has only been assessed at the micro-catchment scale (max. 8 ha; Fiener and Auerswald, 2005; Fiener et al., 2005). Large quantities of concentrated runoff leading to muddy floods cannot be generated on such small surfaces and a specific study is hence needed at the scale of the larger catchments, which are the source areas of muddy floods.

This paper evaluates the effectiveness of a GWW and earthen dams installed in a cultivated 300 ha-catchment in the Belgian loess belt in mitigating muddy floods in the downstream village. The cost-efficiency of the control measures is also discussed. 


\section{Materials and methods}

110

111

112

113

114

115

116

117

118

119

120

121

122

123

124

125

126

127

128

129

130

131

132

133

134

135

136

137

138

139

140

141

142

143

\subsection{General context}

The Belgian loess belt $\left(\sim 9000 \mathrm{~km}^{2}\right)$ is a plateau with a mean altitude of 115 m gently sloping to the North (Fig. 1a). Annual mean temperature varies between $9-10^{\circ} \mathrm{C}$, while annual precipitation ranges from 700-900 mm (Hufty, 2001). Soils are mainly loess-derived Haplic Luvisols (World Reference Base, 1998). Arable land covers $65 \%$ of the total surface (Statistics Belgium, 2006). During the last three decades, the area covered by summer crops (sugar beet - Beta vulgaris L., maize - Zea Mays L., potatoes - Solanum tuberosum L. and chicory - Cichorium intybus L.) increased at the expense of winter cereals (Evrard et al., 2007a). The summer crops provide little cover to the soil during the thunderstorms that occur in late spring or early summer, which leads to the formation of a soil surface crust with a very low infiltration rate. High quantities of runoff are then generated on these crusted soils during intense precipitation (Evrard et al., in press).

The region of Sint-Truiden has been repeatedly affected by muddy floods, and the local water agency (Melsterbeek Water Board) decided to tackle the problem (Fig. 1a). In the framework of the 'Erosion Decree' adopted by the Flemish government in 2001, they drew up an erosion mitigation scheme at the catchment scale $\left(200 \mathrm{~km}^{2}\right)$. Between 2002-2005, 120 grass strips and GWW have been installed, covering a surface of $\sim 25$ ha $(0.13 \%$ of total area). Furthermore, 35 earthen dams have been built.

\subsection{Study area}

Velm has the local reputation of a 'devastated village', since it was flooded several times during the last two decades. Runoff loaded with sediments is generated in cultivated dry zero-order valleys covering a total area of 930 ha that drain to the village (Fig. 1b).

A 300 ha-catchment draining into Velm, locally known as 'Heulen Gracht', was selected for detailed monitoring (Fig. 2). Cropland covers $79 \%$ of the catchment surface. Orchards (17\%) and roads (3\%) are the other main types of land use. A typical topsoil sample in this catchment contains $80 \%$ silt, $10 \%$ clay and $10 \%$ sand and the mean slope reaches $1.3 \%$.

An earthen dam was built close to the catchment outlet in April 2002 to prevent muddy floods (dam \# 3 in Fig. 2). A GWW was also sown in the thalweg in 2003, covering 12 ha ( $4 \%$ of total catchment surface; Fig. 2). Grass species consist of a mix of Lolium 
145 L. Two additional dams were built across the GWW in August 2004 (dams \# 1 and 2 in Fig.

$1462)$.

\subsection{Impact of control measures on runoff}

Rainfall is measured at $0.1 \mathrm{~mm}$ resolution using two tipping bucket rain gauges located at the catchment outlet and just upstream of the GWW (Fig. 2). The catchment was equipped with a discharge measurement station in April 2006. It consists of a San Dimas flume connected with a flowmeter (Sitrans Probe LU, Peterborough, Ontario, Canada). Finally, a water level logger (Global Water-WL 15, Gold River, California, USA) was installed in May 2005 behind each of the three earthen dams built across the GWW. A topographic survey was carried out in Spring 2005 to determine the volume-depth curves of a pipe at the bottom of the dam. Water levels are converted to outflow discharges using Eq. 1 (Ilaco, 1985) :

$160 Q=A \times(2 g h)^{0.5}$

161 where $Q$ is discharge $\left(\mathrm{m}^{3} \mathrm{~s}^{-1}\right) ; A$ is the cross-section of the drain $\left(\mathrm{m}^{2}\right)$; g is gravity acceleration $(9.81 \mathrm{~m}$ $\mathrm{s}^{-2}$ ) and $\mathrm{h}$ is the hydraulic head $(\mathrm{m})$.

163

164 The impact of the control measures on runoff is estimated by comparing peak discharges per unit area $\left(1 \mathrm{~s}^{-1} \mathrm{ha}^{-1}\right)$, runoff coefficients (\%), duration of runoff flow (h) and lag time (h) for each event measured at both the upstream and downstream extremities of the GWW. Since the distribution of these parameters is normal as determined by Kolmogorov-Smirnov tests, paired Student's $t$-tests have been carried out using the SAS Enterprise Guide statistical package (SAS Institute Inc., Cary, North Carolina, USA) to detect any significant differences between both extremities of the GWW at 95\% confidence intervals.

\subsection{Impact of control measures on erosion}

The rills and gullies that were formed during the monitoring period have been mapped, 175 their length, depth and width measured. The cross-sectional area of erosion features has been

176 computed for 67 transects within the catchment. The mass of eroded soil is determined using

177 the mean value of bulk density measured for cropland in loess soils of central Belgium (1.43 $\mathrm{g}$ 
$178 \mathrm{~cm}^{-3}$; Goidts and van Wesemael, 2007). Sediment thickness in the detention pond located

179 behind dam \# 3 (Fig. 2) was measured with an estimated precision of $5 \mathrm{~mm}$ with a meter on a

180 5m-grid after each important rainfall event (with $\geq 10 \mathrm{~mm}$ of cumulative rainfall). Data are

181 interpolated to estimate sediment volume and mass. The calculated erosion rates are compared

182 to the output of an empirical relationship between catchment area (A, ha) and specific

183 sediment yield (SSY, $\mathrm{t} \mathrm{ha}^{-1} \mathrm{yr}^{-1}$ ) obtained for 26 cultivated catchments of the Belgian loess

184 belt over a period of 2-46 years during the $20^{\text {th }}$ century (Eq. 2; Verstraeten and Poesen, 2001).

$185 \quad S S Y=26 A^{-0.35}$

A suspended sediment sampler (ISCO-6712, Lincoln, Nebraska, USA) was installed in the San Dimas flume and connected to the water level sensor in order to determine the erosion rate after the installation of the control measures. Since there is no permanent flow, sampling only occurs when the height of water in the flume exceeds $5 \mathrm{~cm}$. A runoff sample is then taken at a 5 minutes-time step until the end of the event. Suspended sediment concentration is determined by drying the samples in an oven at $105^{\circ} \mathrm{C}$ for 24 hours. Runoff samples have also been taken manually at the outlet of the dam pipes during the heaviest storms to compare the sediment concentrations and discharges with the ones measured in the San Dimas flume. A Student t-test has been carried out to detect significant changes in sediment discharge between both extremities of the GWW.

\subsection{Impact of control measures on muddy floods}

The Sint-Truiden fire brigade classifies its interventions according to their nature (road accident, fire, riverine or muddy flood). Such data are available for Velm village since 1977. Corresponding daily rainfall data are available for the Gorsem (Sint-Truiden) station of the Belgian Royal Meteorological Institute, located $5 \mathrm{~km}$ from the catchment. These muddy flood reports allow a comparison of flood frequency in Velm village before and after the installation 206

\section{Results}

Between 2002-2007, 77\% of events with $\geq 15 \mathrm{~mm}$ precipitation occurred between 


\subsection{Impact of control measures on runoff}

The San Dimas flume recorded 39 runoff events in 2006 and 2007 (Table 2). Runoff coefficients of the catchment upstream of the GWW calculated based on the San Dimas flume discharge varied between $0.07 \%$ and $22.7 \%$, with a mean of $7.4 \%$ (Table 2). Usually, runoff coefficients were higher in spring and summer (8.3\%) than in autumn and winter $(3.8 \%)$. The highest coefficients were measured in August 2006, which was a very wet month, as well as during the extreme event of June 11 2007. The heaviest and most intense storms have led to the highest peak discharges in the flume $\left(0.44 \mathrm{~m}^{3} \mathrm{~s}^{-1}\right.$ on June 142006 and $1.47 \mathrm{~m}^{3} \mathrm{~s}^{-1}$ on June 11 2007; Table 2).

Some 53 rainfall-runoff events have been measured behind the dams (Table 2). Before the installation of dams 2 and 3 in August 2004 (Fig. 2), runoff events with a discharge $\geq$ $0.03 \mathrm{~m}^{3} \mathrm{~s}^{-1}$ have been observed at dam 3 during low-intensity precipitation (e.g. in February, 2003; Table 2). After the installation of the two additional dams, notable runoff has been measured behind the dam at the outlet (dam 3; Fig. 2) during only 13 events. These events correspond to: (i) prolonged periods of rain in winter ( $\geq 30 \mathrm{~mm}$ in 48 hours) or (ii) to heavy thunderstorms between May and August ( $\geq 20 \mathrm{~mm}$ in a few hours). All runoff parameters are significantly different between both extremities of the GWW at the $95 \%$ confidence interval (Table 3).

An important and significant decrease of the peak discharge per unit area (mean of $69 \%$ ) was observed between the San Dimas flume (just upslope of the GWW) and the catchment outlet. Loss of runoff, probably due to infiltration in the GWW and behind the dams, has also been observed. Runoff coefficients decreased by a mean of $40 \%$ between both extremities of the GWW (Table 3). The reduction was higher during low-intensity rainfall (mean of $43 \%$ for events with an $I_{\max }<40 \mathrm{~mm} \mathrm{~h}^{-1}$ ) than during intense thunderstorms (mean of $20 \%$ for events with an $I_{\max }>40 \mathrm{~mm} \mathrm{~h}^{-1}$; Table 2).

Runoff was buffered during 5-12 hours behind the three successive dams. The mean duration of runoff was $38 \%$ longer at the outlet than just upstream of the GWW. A long hydrograph recession limb, corresponding to the progressive outflow of runoff buffered behind the dams through the pipes, was observed. The lag time increased by a mean of $75 \%$ after the installation of the control measures.

Peak flow left the San Dimas flume and reached the outlet of the first dam in a mean of 2 hours 25 minutes (mean propagation velocity of the peak discharge of $0.04 \mathrm{~m} \mathrm{~s}^{-1}$ ). Peak outflow from the first dam reached the outlet of the second pond in a mean of 32 minutes 
246 (mean propagation velocity of $0.09 \mathrm{~m} \mathrm{~s}^{-1}$ ). Some 64 minutes were then needed for peak runoff

247 to reach the outlet of the third dam (mean propagation velocity of $0.14 \mathrm{~m} \mathrm{~s}^{-1}$ ). The

248 propagation of the peak discharge was hence slowed down in the GWW, but the decrease was not linear between the dams (Table 2).

250

251

252

253

254

255

256

257

258

259

260

261

262

263

264

265

266

267

268

269

270

271

272

273

274

275

276

277

278

279

280

\subsection{Impact of control measures on specific sediment yield}

According to Eq. (2), the specific sediment yield for a catchment of the size of the Heulen Gracht should be $3.5 \mathrm{t} \mathrm{ha}^{-1} \mathrm{yr}^{-1}$. The gullies observed since the $1940 \mathrm{~s}$ and draining to Velm are mapped in Fig. $1 b$.

Six major erosion events have been documented between April-September 2002 (Table 4). The first erosion event occurred in May 2002. The summer crops were already sown at that time, and tillage erased erosion features remaining from the winter period. Total volume of the rills and gullies reached $\sim 1500 \mathrm{~m}^{3}$ in September 2002, corresponding to a soil loss due to rill and gully erosion of $2175 \mathrm{~T}$. Rill and gully cross-section was very variable $(0.2$ $-2.5 \mathrm{~m}^{2}$ ), both between and within fields. Erosion rate reached a mean value of $7.25 \mathrm{tha}^{-1}$ at the catchment scale in 2002, without taking sheet erosion into account.

Measurements of sediment concentrations in the flume as well as in the outflow of the dams are available for 13 events recorded in 2006 and 2007 (Table 5). Much of the sediment was trapped behind the first dam. Sediment concentration in the first dam's outflow is decreased by a mean of $86 \%$ compared to the concentration measured in the San Dimas flume. It further decreased by $16 \%$ due to trapping behind the second dam. In contrast, an increase of sediment concentration $(+38 \%)$ was generally measured at the catchment outlet compared to the second dam outflow. This is due to the inflow of runoff loaded with sediments, flowing from row crop fields located along this part of the GWW. However, sediment concentrations at the outlet were reduced by a mean of $88 \%\left(0.9 \mathrm{~g} \mathrm{l}^{-1}\right)$ compared to the ones measured in the flume (mean of $5.4 \mathrm{~g} \mathrm{l}^{-1}$ ). Sediment discharge was reduced by a mean of $93 \%$, decreasing from $3.2 \mathrm{~kg} \mathrm{~s}^{-1}$ in the flume to $0.2 \mathrm{~kg} \mathrm{~s}^{-1}$ at the outlet. However, this difference was not statistically significant at $95 \%$ confidence interval (Table 3 ). This is probably due to the rather low number of events for which sediment data are available, as well as to the important seasonal variation of runoff and sediment production on cropland in the Belgian loess belt. Rainfall simulations have shown that sediment production is much lower on crusted soils in August $\left(3 \mathrm{~g} \mathrm{l}^{-1}\right)$ than on fragmentary soils $\left(40 \mathrm{~g}^{-1}\right)$ at the end of spring (Evrard et al., in press). During the extreme event of June 11 2007, 84 t of sediments were 
trapped behind the three successive dams. It represents $72 \%$ of soil loss measured in the San

282 Dimas flume. No more rills have been observed in the thalweg since the sowing of the GWW

283 and the construction of the dams despite the occurrence of several extreme events.

284

285

286

287

288

289

290

291

292

293

294

295

296

297

\subsection{Impact of control measures on muddy floods}

Soil erosion and flooding are ancient problems in the area. Flooding of the nearby Gingelom village was already very frequent during the $18^{\text {th }}$ century (Aumann and Vandenghoer, 1989). Intense soil erosion was explicitly mentioned in the 1960s for the nearby Gingelom village (Fig. 1b; T'Jonck, 1967). However, the off-site consequences have become more frequent during the last two decades (Evrard et al., 2007a). Fire brigade interventions due to muddy floods in the Velm village dramatically increased since 1980 (Table 4). All muddy floods were triggered by heavy thunderstorms (between 14-70 $\mathrm{mm}$ of rainfall, with a mean of $35.5 \mathrm{~mm}$ ) and occurred between May and August (Table 4). Six heavy storms (20-70 $\mathrm{mm}$ precipitation) occurred in 2002, each leading to the flooding of the village. The three events in August 2002 were rather extreme, having a return period between 20- and $>200$ years (after Delbeke, 2001).

Since the installation of the GWW and the two additional earthen dams in 2004, no muddy flood has been recorded in Velm village, despite the occurrence of several extreme events (Table 2). The measures have particularly served their purpose during the extreme event of June 112007 (having a return period of 150 years, according to Delbeke, 2001), buffering runoff during 17 hours and preventing any flood in Velm village (Fig. 4). Peak discharge per unit area decreased by $79 \%$ and the lag time dramatically increased (from 10 minutes in the flume to 5 hours 30 minutes at the outlet).

\section{Discussion}

\subsection{Effectiveness of the grassed waterway and earthen dams}

The propagation of the peak discharge was drastically slowed down within the section with the GWW and the earthen dams. However, there was no important reinfiltration in GWW for moderate and extreme storms. This is due to a high soil compaction (bulk density of $1.59 \mathrm{~g} \mathrm{~cm}^{-3}$ in the GWW compared to a mean of $1.43 \mathrm{~g} \mathrm{~cm}^{-3}$ for cropland in the Belgian loess belt according to Goidts and van Wesemael, 2007). This confirms the results of rainfall 
316 simulations carried out in the Belgian loess belt showing that grass strips and GWW have a

317 higher runoff coefficient (62-73\%) than most cultivated soils (13-58\%; Evrard et al., in press).

318 Sediment trapping is very high and occurs mainly behind the first dam, except during

319 extreme events. These observations confirm the main results of a former modelling exercise

320 (Evrard et al., 2007b). The model simulated that the GWW led to a 50\% decrease of peak

321 discharge, which is consistent with field observations. Our findings also agree with the results

322 of a similar study analysing the impact of a GWW on runoff and erosion in a micro-catchment

323 (8 ha) in southern Germany (Fiener and Auerswald, 2005; Fiener et al., 2005). The German

324 ponds were very efficient in trapping sediments (between $50-80 \%$ of sediments were trapped)

325 and reducing peak runoff rates. However, two main differences with our study can be

326 outlined, besides the different catchment sizes. In Germany, no event having a return period

327 of $>5$ years occurred during the 9-year experiment, while we observed that the dams

328 particularly served their purpose during extreme events. Furthermore, an intensive soil and

329 water conservation scheme was implemented in the German catchments draining to the ponds,

330 limiting sediment and runoff inputs (Auerswald et al., 2000). Our study shows that even

331 without widespread implementation of alternative farming practices, the measures are

332 effective in controlling muddy floods. They offer, therefore, a solution that can be

333 implemented in the short term to protect the most endangered villages against muddy floods.

\subsection{Evaluation of erosion rates and sediment delivery}

Based on field measurements in 2002, rill and gully erosion rates reached $7.25 \mathrm{tha}^{-1}$

338 for that specific year. This figure does not take sheet erosion into account. Often, interrill

339 erosion has been estimated as a fraction of total soil loss. This fraction ranges between 10-

$34020 \%$ of the total soil loss in the Belgian loess belt (Govers and Poesen, 1988; Takken et al.,

341 1999; Steegen et al., 2000). Total erosion was hence underestimated in our study and should

342 be close to $8.3 \mathrm{tha}^{-1}$. This figure is consistent with the range of annual erosion rates measured

343 in central Belgium (6.5-12.3 $\mathrm{t} \mathrm{ha}^{-1} \mathrm{yr}^{-1}$; Verstraeten et al., 2006).

344 Nachtergaele and Poesen (1999) calculated a mean ephemeral gully erosion rate of

$3452.33 \mathrm{t} \mathrm{ha}^{-1} \mathrm{yr}^{-1}$ (over a six months period during which summer ephemeral gullies remain

346 active). The ephemeral gully in the thalweg of the Heulen Gracht Catchment was observed on

347 all aerial photographs available for the study area (between 1947-1996), always appearing at

348 the same location (Fig. 1b). Hence, no increase of gully erosion throughout the study period 
was found. The highest erosion rate was even observed in $1947\left(3.43 \mathrm{t} \mathrm{ha}^{-1} \mathrm{yr}^{-1}\right)$, which shows that erosion is not a recent phenomenon in the study area.

Steegen (2001) showed that summer extreme events have a particularly important effect on long-term landscape evolution. For instance, a summer rainfall with a 10 year-return period that occurred in a 250 ha-catchment in the Belgian loess belt exported several times the mean long-term erosion rate $\left(7 \mathrm{tha}^{-1} \mathrm{yr}^{-1}\right.$ for the extreme event, after Steegen et al., 2000; vs. $2.6 \mathrm{tha}^{-1} \mathrm{yr}^{-1}$ for the long-term mean, after Vandaele, 1997).

During the extreme event of June 2007, the three ponds trapped sediments ( $84 \mathrm{t}$ in total). Since the control measures prevent the formation of rills and gullies in the catchment, erosion rates are dramatically reduced. Only interrill erosion is still observed at a mean rate of $0.5 \mathrm{tha}^{-1} \mathrm{yr}^{-1}$, thereby drastically decreasing sediment delivery to the alluvial plain.

\subsection{Cost-efficiency of control measures}

Immediately after thunderstorms, people need assistance from the fire brigade and municipal services to pump water from cellars and clean up the roads. Fire brigade interventions after the thunderstorms of August 2002 in the Melsterbeek Catchment (Fig. 1a) cost $\sim € 25,000$ (i.e. $125 € \mathrm{~km}^{-2}$ ). Muddy floods also led to numerous cases of damage to private property. According to 1601 records submitted by Belgian households to the Disaster Fund, mean damage amount was $€ 4,436$ ( $S D=3,406 €$; Evrard et al., 2007a). The villages of Velm and Gingelom were particularly affected by the thunderstorms of May and August 2002 (Table 4). Households from these two villages submitted 268 records to the Belgian Disaster Fund. They received $€ 636,967$ (mean of $€ 2,377$ per record).

Overall, muddy floods lead to a damage cost of $54 € \mathrm{ha}^{-1} \mathrm{yr}^{-1}$ in the region of Velm. Total cost of the control measures installed in the area reached $126 € \mathrm{ha}^{-1}$. The measures are built for a 20 year-period according to the Soil Erosion Decree. Farmers receive additional subsidies each year for the maintenance of grass strips $\left(21 € \mathrm{ha}^{-1} \mathrm{yr}^{-1}\right)$. Compared to the damage cost of muddy floods $\left(54 € \mathrm{ha}^{-1} \mathrm{yr}^{-1}\right)$, the investments would be cost-efficient in $\sim 3$ years if the measures are effective and no muddy flood occurs. Our results prove that the measures serve their purpose. In Velm village, total investment $(€ 351,528)$ represents the damage cost to private properties caused by the single August 2002 flood.

The Flemish authorities calculated that the construction of all the control measures proposed in the municipal erosion mitigation schemes that were approved by their administration would cost between 7.7-9.6 million $€ \mathrm{yr}^{-1}$ during the period 2006-2025, which 
383 is not disproportionate compared with the total damage cost associated with muddy floods in

384 the Flemish municipalities of the Belgian loess belt (between 8-86 million $€ \mathrm{yr}^{-1}$; Evrard et al., 385 2007a).

386

387

388

389

390

391

392

393

394

395

396

397

398

399

400

401

402

403

404

405

406

407

408

409

410

411

412

413

414

415

416

417

418

419

\section{Conclusions}

A 12 ha-grassed waterway and three earthen dams were installed in a 300 hacultivated catchment in central Belgium, in order to prevent muddy floods in the downstream village. These measures served their purpose by preventing muddy floods in the village, even during extreme events (with a maximum return period of 150 years). Peak discharge per unit area was reduced by a mean of $69 \%$ between both extremities of the GWW. Furthermore, runoff was buffered during 5-12 hours, due to the combined effect of the GWW and the earthen dams. The lag time increased by $75 \%$ after the installation of the control measures. Sediment discharge at the catchment outlet decreased by a mean of $93 \%$ compared to the one measured in the GWW's runoff inflow. The measures also prevented any gully formation in the thalweg, thereby reducing erosion to an interrill phenomenon which occurs at a mean rate of $0.5 \mathrm{tha}^{-1} \mathrm{yr}^{-1}$, whereas the specific sediment yield of a catchment of similar size without control measures in the Belgian loess belt should reach $3.5 \mathrm{t} \mathrm{ha}^{-1} \mathrm{yr}^{-1}$. This would dramatically decrease sediment transfer from the cultivated dry valley to the alluvial plain. Given they prevent muddy floods and remain cost-efficient, similar control measures can be installed to protect other flood prone areas in the Belgian loess belt and comparable environments. These measures could be combined with alternative farming practices, such as reduced tillage. However, there is a need to study the impact of these practices on runoff and erosion at the catchment scale.

\section{Acknowledgements}

The authors thank Marco Bravin for his technical assistance in installing the catchment loggers and measurement station and Elisabeth Frot for her help with data collection in 2002. The installation of the measurement devices was financially supported by the Land Division of the Flemish Ministry of Environment, Nature and Energy. Local farmers (Jean Lejeune, Jean Boonen and Roland Meys) are also gratefully thanked for implementing the erosion control measures. 


\section{References}

Aumann, F., Vandenghoer, C., 1989. Baron Surlet de Chokier, regent van België: Mens en Mythe (1769-1839). (In Dutch). Gemeentebestuur Gingelom.

Auerswald, K., Albrecht, H., Kainz, M., Pfadenhauer, J., 2000. Principles of sustainable landuse systems developed and evaluated by the Munich Research Alliance on AgroEcosystems (FAM). Petermanns Geographische Mitteilungen 144 (2), 16-25.

Bielders, C.L., Ramelot, C., Persoons, E., 2003. Farmer perception of runoff and erosion and extent of flooding in the silt-loam belt of the Belgian Walloon Region. Environmental Science \& Policy 6, 85-93.

Bork, H.-R., Bork, H., Dalchow, C., Faust, B., Piorr, H.-P., Schatz, T., 1998. Landschaftsentwicklung in Mitteleuropa. (In German). Klett-Perthes, Gotha.

Boardman, J., Evans, R., Ford, J., 2003. Muddy floods on the South Downs, southern England: problem and responses. Environmental Science \& Policy 6, 69-83.

Boardman, J., Verstraeten, G., Bielders, C., 2006. Muddy floods. In: Boardman, J., Poesen, J. Soil Erosion in Europe. Wiley, Chichester, pp. 743-755.

Delbeke, L., 2001. Extreme neerslag in Vlaanderen. (In Dutch). Technical report. Aminal, Afdeling Water. Ministerie van de Vlaamse Gemeenschap.

de Moor, J.J.W., Verstraeten, G., in press. Alluvial and colluvial sediment storage in the Geul River catchment (The Netherlands) - Combining field and modelling data to construct a Late Holocene sediment budget. Geomorphology.

Evrard, O., Bielders, C.L., Vandaele, K., van Wesemael, B., 2007a. Spatial and temporal variation of muddy floods in central Belgium, off-site impacts and potential control measures. Catena 70, 443-454.

Evrard, O., Persoons, E., Vandaele, K., van Wesemael, B., 2007b. Effectiveness of erosion mitigation measures to prevent muddy floods: A case study in the Belgian loam belt. Agriculture Ecosystems \& Environment 118, 149-158.

Evrard, O., Vandaele, K., Bielders, C.L., van Wesemael, B., in press. Seasonal evolution of runoff generation on agricultural land in the Belgian loess belt and implications for muddy flood triggering. Earth Surface Processes \& Landforms.

Fiener, P., Auerswald, K., 2005. Seasonal variation of grassed waterway effectiveness in reducing runoff and sediment delivery from agricultural watersheds in temperate Europe. Soil \& Tillage Research 87 (1), 48-58. 
Fiener, P., Auerswald, K., Weigand, S., 2005. Managing erosion and water quality in agricultural watersheds by small detention ponds. Agriculture Ecosystems \& Environment 110 (3-4), 132-142.

Goidts, E., van Wesemael, B., 2007. Regional assessment of soil organic carbon changes under agriculture in Southern Belgium (1955-2005). Geoderma 141, 341-354.

Govers, G., Poesen, J., 1988. Assessment of the interrill and rill contributions to total soil loss from an upland field plot. Geomorphology 1, 343-354.

Gyssels, G., Poesen, J., Nachtergaele, J., Govers, G., 2002. The impact of sowing density of small grains on rill and ephemeral gully erosion in concentrated flow zones. Soil \& Tillage Research 64 (3-4), 189-201.

Holland, J.M., 2004. The environmental consequences of adopting conservation tillage in Europe: reviewing the evidence. Agriculture, Ecosystems \& Environment 103 (1), 125 .

Hufty, A., 2001. Introduction à la climatologie. (In French). Ed. De Boeck Université, Brussels, $542 \mathrm{p}$.

Ilaco, 1985. Agricultural compendium for rural development. Elsevier, Amsterdam.

Lang, A., Bork, H.-R., Mäkel, R., Preston, N., Wunderlich, J., Dikau, R., 2003. Changes in sediment flux and storage within a fluvial system: some examples from the Rhine catchment. Hydrological Processes 17, 3321-3334.

Le Bissonnais, Y., Lecomte, V., Cerdan, O., 2004. Grass strip effects on runoff and soil loss. Agronomie 24, 129-136.

Leys, A., Govers, G., Gillijns, K., Poesen, J., in press. Conservation tillage on loamy soils: explaining the variability in interrill runoff and erosion reduction. European Journal of Soil Science.

Nachtergaele, J., Poesen, J., 1999. Assessment of soil losses by ephemeral gully erosion using high-altitude (stereo) aerial photographs. Earth Surface Processes \& Landforms 24, 693-706.

Nachtergaele, J., Poesen, J., 2002. Spatial and temporal variations in resistance of loessderived soils to ephemeral gully erosion. European Journal of Soil Science 53, 449463.

Patty, L., Réal, B., Gril, J.J., 1997. The use of grassed buffer strips to remove pesticides, nitrate and soluble phosphorus compounds of water. Pesticide Science 49, 243-251.

Rommens, T., Verstraeten, G., Poesen, J., Govers, G., Van Rompaey, A., Peeters, I., Lang, A., 2005. Soil erosion and sediment deposition in the Belgian loess belt during the 
Holocene: establishing a sediment budget for a small agricultural catchment. The Holocene 15(7), 1032-1043.

Rommens, T., Verstraeten, G., Bogman, P., Peeters, I., Poesen, J., Govers, G., Van Rompaey,

492

493

494

495

496

497

498

499

500

501

502

503

504

505

506

507

508

509

510

511

512

513

514

515

516

517

518

519

520

521 A., Lang, A., 2006. Holocene alluvial sediment storage in a small river catchment in the loess area of central Belgium. Geomorphology 77, 187-201.

Souchère, V., King, C., Dubreuil, N., Lecomte-Morel, V., Le Bissonnais, Y., Chalat, M., 2003. Grassland and crop trends: role of the European Union Common Agricultural Policy and consequences for runoff and soil erosion. Environmental Science \& Policy 6, 7-16.

Statistics Belgium, 2006. URL: http://www.statbel.fgov.be

Steegen, A., Govers, G., Nachtergaele, J., Takken, I., Beuselinck, L., Poesen, J., 2000. Sediment export by water from an agricultural catchment in the Loam Belt of central Belgium. Geomorphology 33, 25-36.

Steegen A., 2001. Sediment deposition in and export from small agricultural catchments. Unpublished PhD thesis, Faculty of Sciences, Geography, K.U. Leuven.

Takken, I., Beuselinck, L., Nachtergaele, J., Govers, G., Poesen, J., Degraer, G., 1999. Spatial evaluation of a physically-based distributed erosion model (LISEM). Catena 37, 431447.

T'Jonck, G., 1967. La lutte contre l'érosion. Un cas à Gingelom. L'amélioration de la structure agraire : problèmes techniques particuliers. (In French). Société Nationale Terrienne, 9-15.

Vandaele, K., 1997. Temporele en ruimtelijke dynamiek van bodemerosieprocessen in landelijke stroomgebieden (Midden-België): een terreinstudie. (In Dutch). Unpublished PhD thesis, Faculty of Sciences, Geography, K.U. Leuven.

Van Dijk, P.M., Kwaad, F.J.P.M., Klapwijk, M., 1996. Retention of water and sediment by grass strips. Hydrological Processes 10, 1069-1080.

Verstraeten, G., Poesen, J., 1999. The nature of small-scale flooding, muddy floods and retention pond sedimentation in central Belgium. Geomorphology 29, 275-292.

Verstraeten, G., Poesen, J., 2001. Factors controlling sediment yield from small intensively cultivated catchments in a temperate humid climate. Geomorphology 40, 123-144.

Verstraeten, G., Poesen, J., Govers, G., Gillijns, K., Van Rompaey, A., Van Oost, K., 2003. Integrating science, policy and farmers to reduce soil loss and sediment delivery in Flanders, Belgium. Environmental Science \& Policy 6, 95-103. 
529

530

531

532

533

534

535

536

537

538

539

540

541

542

543

544

545

546

547

548

549

Verstraeten, G., Poesen, J., Goossens, D., Gillijns, K., Bielders, C., Gabriels, D., Ruysschaert, G., Van Den Eeckhaut, M., Vanwalleghem, T., Govers, G., 2006. Belgium. In : Boardman, J., Poesen, J. Soil Erosion in Europe. Wiley, Chichester, pp. 385-411.

World Reference Base, 1998. World Reference Base for Soil Resources. FAO, World Resources Report n`84, Rome, Italy.

\section{Figure captions}

Fig. 1. (a) Location of Melsterbeek Catchment and Velm village in the Belgian loess belt. (b) Network of dry valleys draining to Velm village. Dotted lines represent historical gullies and rills observed in the area.

Fig. 2. Land use and location of muddy flood control measures within the Heulen Gracht Catchment.

Fig. 3. Monthly distribution of observed rainfall events during the period 2003-2007 with > $15 \mathrm{~mm}$ of cumulative precipitation, and number of recorded runoff events.

Fig. 4. Rainfall, inflow and outflow hydrographs measured during the thunderstorm of June 112007. 
THE NETHERLANDS

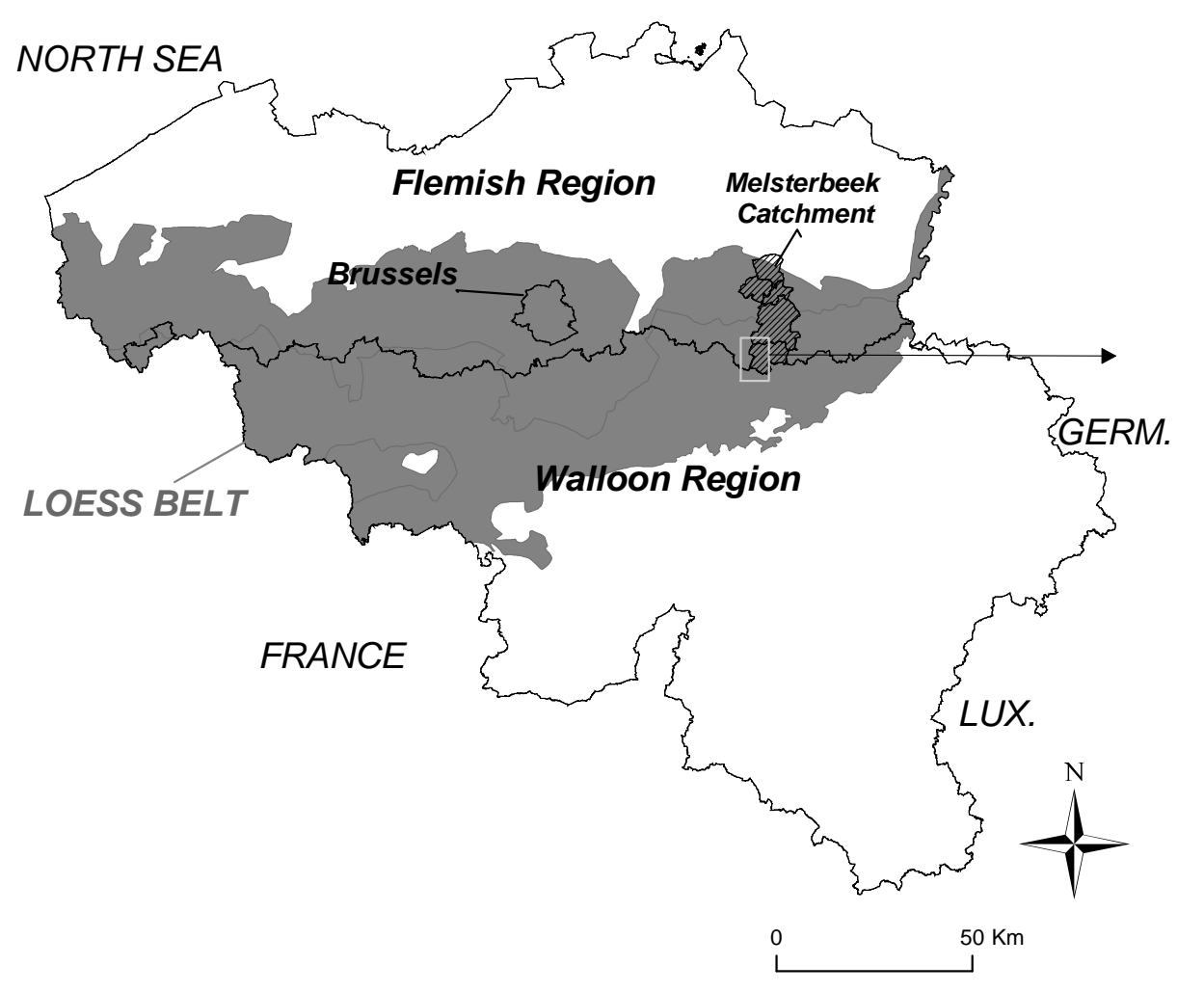

(a)

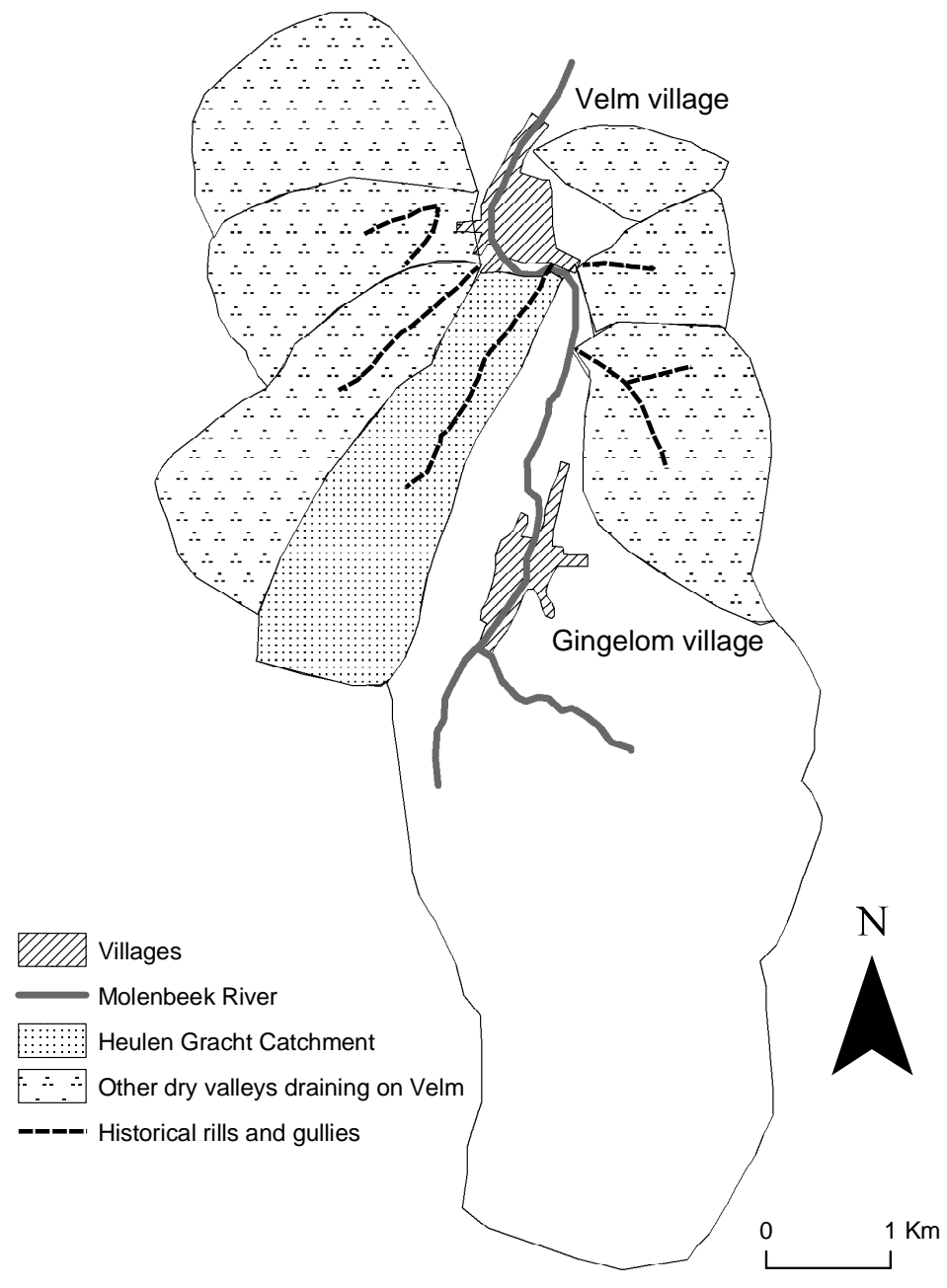

(b)

Fig. 1 
Figure 2

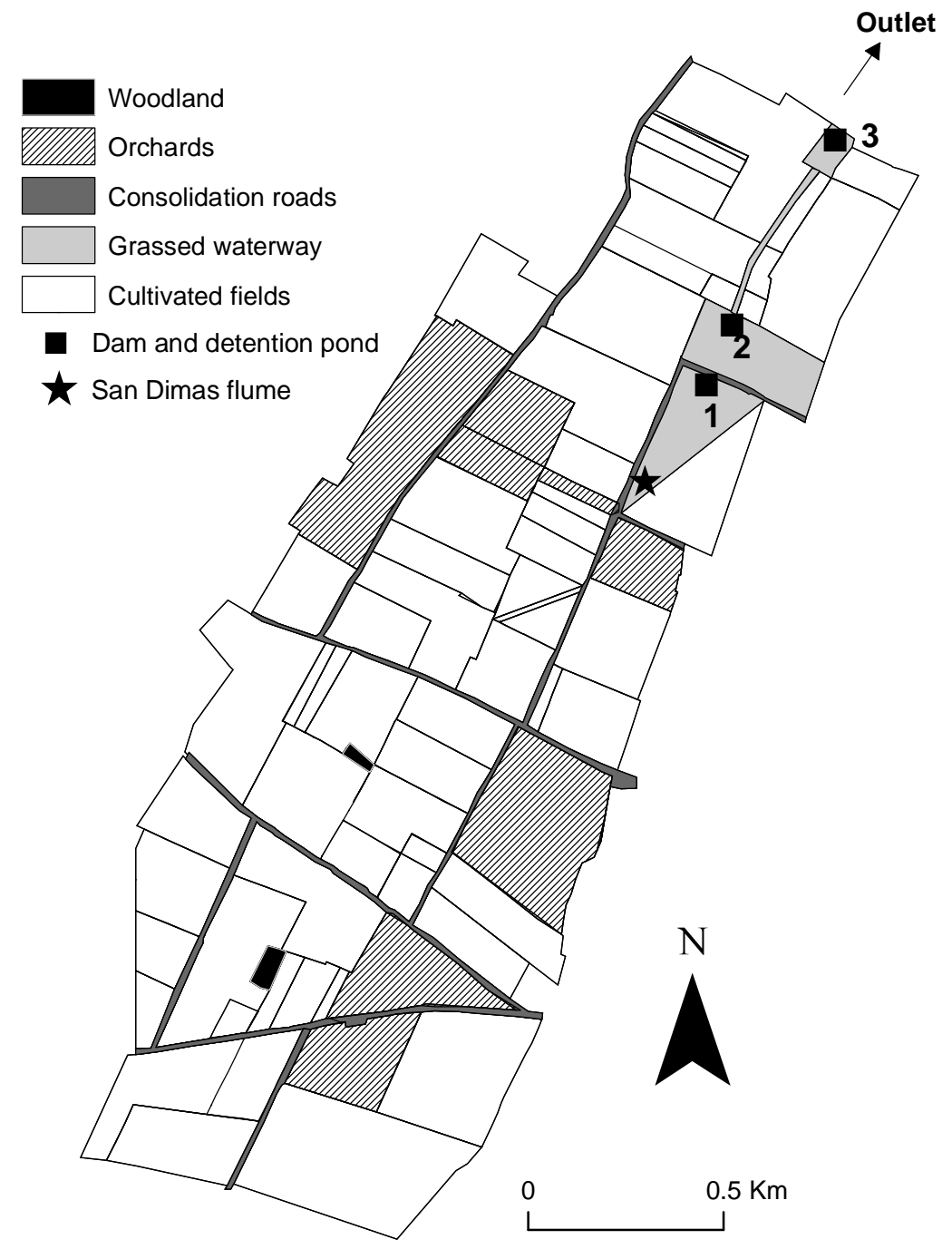

Fig. 2 
Figure 3

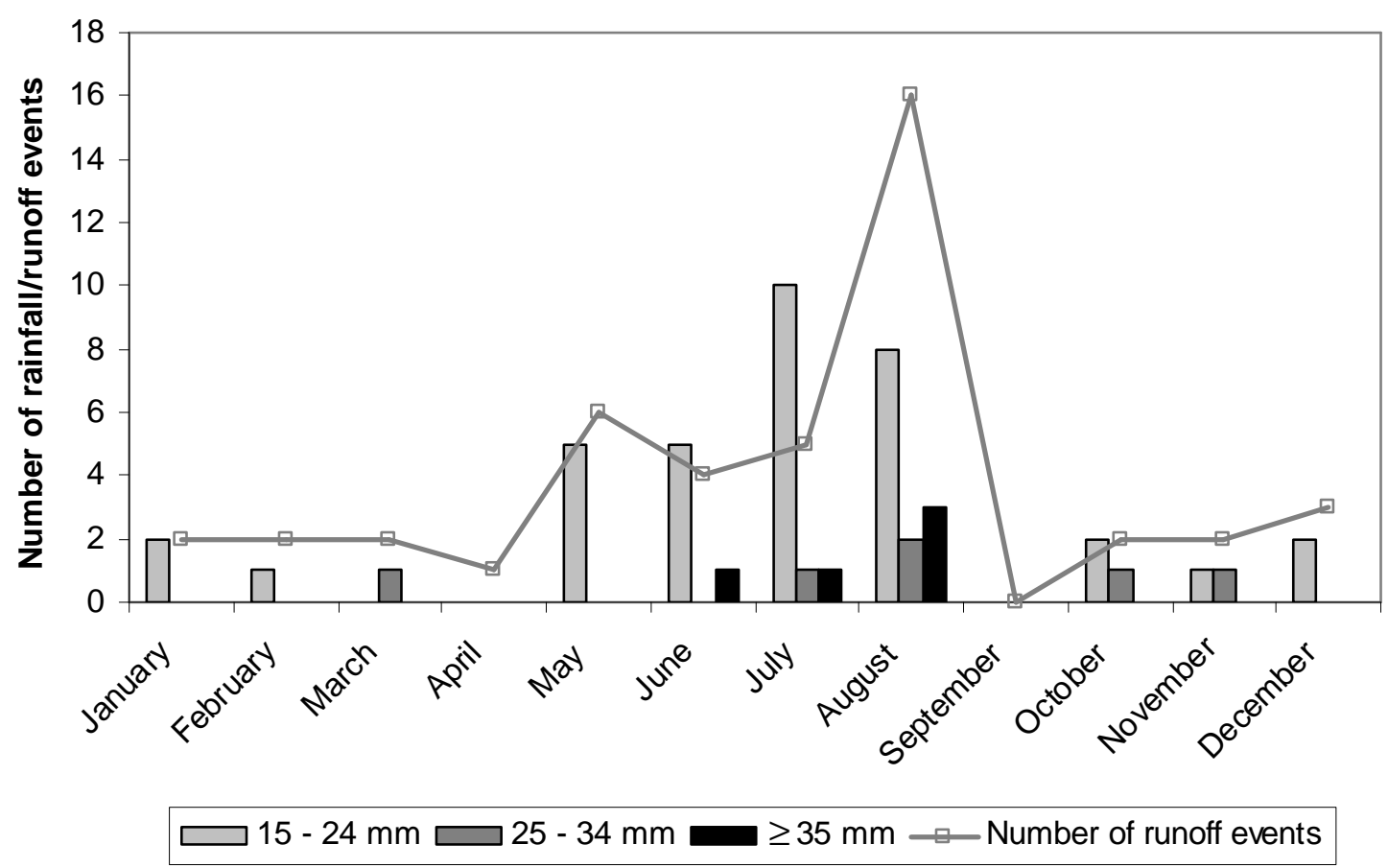

Fig. 3 
Figure 4

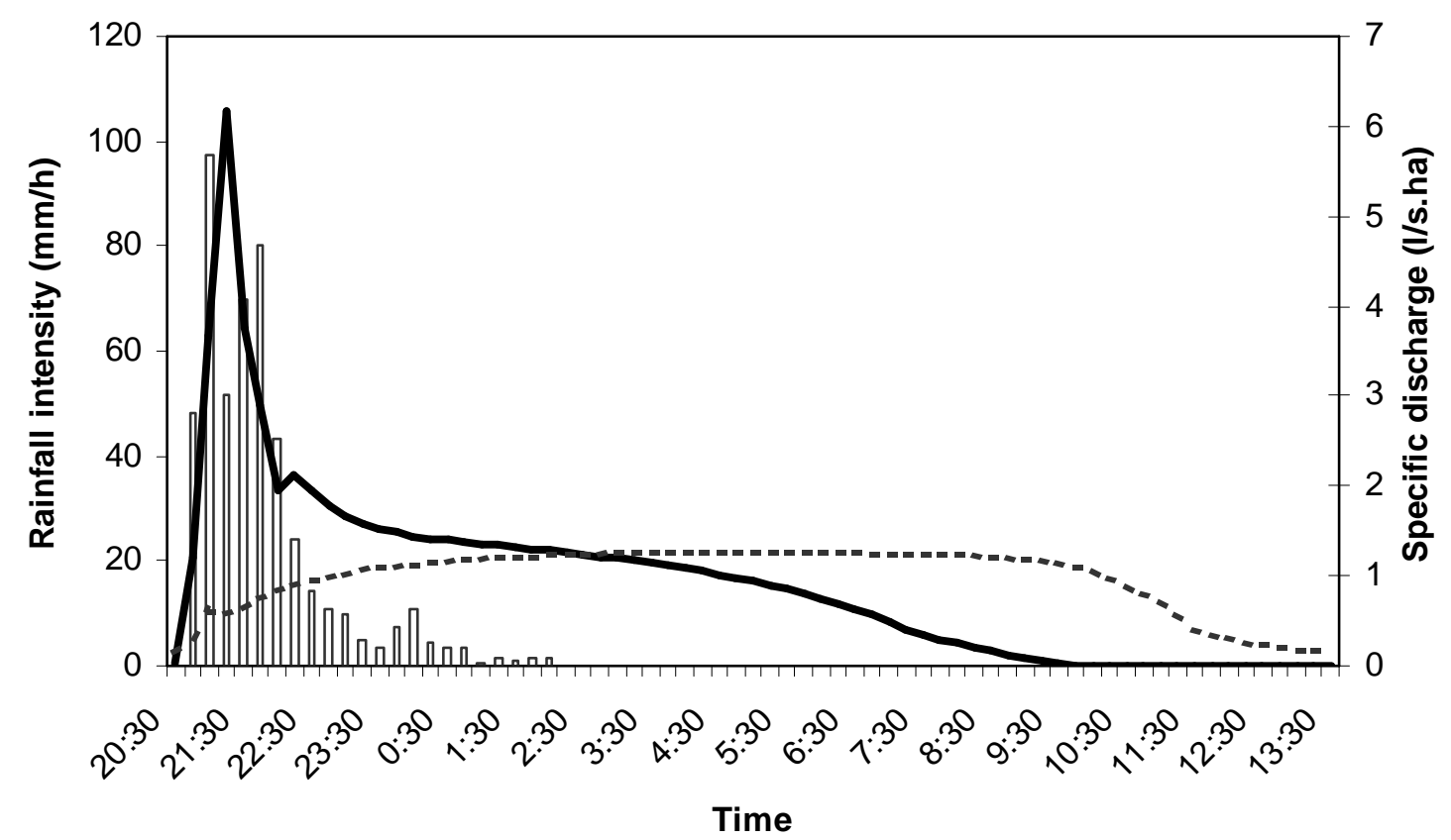

Rainfall (mm/h) $\longrightarrow$ Q (flume) - - - - Q (outlet)

Fig. 4 
Table 1. Characteristics of the detention ponds of the Heulen Gracht Catchment. Location of the ponds is given in Fig. 2

\begin{tabular}{lllllc}
\hline Pond & $\begin{array}{l}\text { Max. dam } \\
\text { Height }(\mathrm{m})\end{array}$ & $\begin{array}{l}\text { Width of } \\
\text { overflow }(\mathrm{m})\end{array}$ & $\begin{array}{l}\text { Max. storage } \\
\text { volume }\left(\mathrm{m}^{3}\right)\end{array}$ & $\begin{array}{l}\text { Diameter } \\
\text { orifice plates }(\mathrm{m})\end{array}$ & $\begin{array}{c}\text { Volume / catch. } \\
\text { area }(\mathrm{mm})\end{array}$ \\
\hline 1 & 2.1 & 10.5 & 3500 & $0.2 / 0.25$ & 1.46 \\
2 & 2.2 & 12.6 & 6200 & $0.2 / 0.2$ & 2.38 \\
3 & 0.95 & 3.0 & 2000 & $0.25 / 0.25$ & 0.67 \\
& & & & \\
\hline
\end{tabular}


Table 2. Results of runoff measurements in the San Dimas flume and the detention ponds of the Heulen Gracht Catchment

\begin{tabular}{|c|c|c|c|c|c|c|c|c|c|c|c|c|c|}
\hline \multirow[b]{2}{*}{$\begin{array}{l}\text { Date } \\
(\mathrm{d} / \mathrm{m} / \mathrm{y})\end{array}$} & \multicolumn{4}{|c|}{ Rainfall data } & \multicolumn{2}{|c|}{ Flume } & \multicolumn{2}{|c|}{ Pond \# 1} & \multicolumn{2}{|c|}{ Pond \# 2} & \multicolumn{2}{|c|}{ Pond \# $3^{a}$} & \multirow[b]{2}{*}{$\begin{array}{l}\mathrm{RC} \\
(\%)\end{array}$} \\
\hline & $\begin{array}{c}\mathrm{A} \\
(\mathrm{mm})\end{array}$ & $\begin{array}{r}\text { D } \\
\text { (h) }\end{array}$ & $\begin{array}{c}\mathrm{T} \\
(\mathrm{yr})\end{array}$ & $\begin{array}{l}\mathrm{I}_{\max } \\
\left(\mathrm{mm} \cdot \mathrm{h}^{-1}\right)\end{array}$ & $\begin{array}{c}\mathrm{Q} \\
\left(\mathrm{m}^{3} \cdot \mathrm{s}^{-1}\right)\end{array}$ & $\begin{array}{l}\mathrm{RC} \\
(\%)\end{array}$ & $\begin{array}{c}\mathrm{Q} \\
\left(\mathrm{m}^{3} \cdot \mathrm{s}^{-1}\right)\end{array}$ & $\begin{array}{l}\text { D } \\
\text { (h) }\end{array}$ & $\begin{array}{c}\mathrm{Q} \\
\left(\mathrm{m}^{3} \cdot \mathrm{s}^{-1}\right)\end{array}$ & $\begin{array}{l}\text { D } \\
\text { (h) }\end{array}$ & $\begin{array}{c}\mathrm{Q} \\
\left(\mathrm{m}^{3} \cdot \mathrm{s}^{-1}\right)\end{array}$ & $\begin{array}{r}\text { D } \\
\text { (h) }\end{array}$ & \\
\hline $09 / 05 / 2002$ & 20 & 1 & 15 & & & & & & & & 0.48 & & \\
\hline $20 / 06 / 2002$ & 25 & 1 & 10 & & & & & & & & 0.36 & & \\
\hline 03/08/2002 & 25 & 0.5 & 20 & & & & & & & & 0.11 & & \\
\hline $20 / 08 / 2002$ & 50 & 3 & 75 & & & & & & & & 0.22 & & \\
\hline $28 / 08 / 2002$ & 70 & 1 & $>2$ & 200 & & & & & & & $>0.5$ & & \\
\hline $06 / 02 / 2003$ & 10 & 24 & $<2$ & & & & & & & & 0.05 & & \\
\hline $24 / 05 / 2003$ & 20 & 5 & $<2$ & & & & & & & & 0.05 & & \\
\hline 03/07/2003 & 18 & 2 & 2 & & & & & & & & 0.05 & & \\
\hline $29 / 08 / 2003$ & 40 & 24 & 5 & & & & & & & & 0.06 & & \\
\hline 08/07/2004 & 14.2 & 8 & $<2$ & & & & & & & & 0.05 & & \\
\hline $17 / 07 / 2004$ & 12.2 & 5.3 & $<2$ & & & & & & & & 0.05 & & \\
\hline $21 / 07 / 2004$ & 20 & 0.2 & 25 & & & & & & & & 0.28 & & \\
\hline $23 / 07 / 2004$ & 23.2 & 4 & 2 & & & & & & & & 0.28 & & \\
\hline $08 / 08 / 2004$ & 11 & 0.8 & $<2$ & & & & & & & & 0.05 & & \\
\hline $13 / 08 / 2004$ & 11.2 & 23 & $<2$ & & & & & & & & 0.05 & & \\
\hline $14 / 08 / 2004$ & 20.6 & 14 & $<2$ & & & & & & & & 0.26 & & \\
\hline 01/07/2005 & 17.4 & 0.8 & 2 & & & & 0.08 & 7.25 & 0.23 & 16.5 & $<0.03$ & & \\
\hline $14 / 08 / 2005$ & 36.6 & 20.5 & 5 & & & & NA & & NA & & 0.07 & & \\
\hline $23 / 10 / 2005$ & 25.6 & 12 & $<2$ & & & & 0.04 & 7.5 & 0 & & $<0.03$ & & \\
\hline $25 / 10 / 2005$ & 14.8 & 10 & $<2$ & & & & 0.05 & 6.75 & 0 & & $<0.03$ & & \\
\hline $31 / 03 / 2006$ & 26 & 21 & $<2$ & & & & 0.08 & 10.7 & 0.08 & 12.33 & 0.09 & 2 & \\
\hline $01 / 04 / 2006$ & 7 & 14 & $<2$ & & & & 0.06 & 6.33 & 0.06 & 7 & $<0.03$ & & \\
\hline $05 / 05 / 2006$ & 10.8 & 3 & $<2$ & 38 & 0.008 & 0.07 & 0 & & 0 & & $<0.03$ & & \\
\hline $18 / 05 / 2006$ & 6 & 1 & $<2$ & 34 & 0.03 & 2 & 0 & & 0 & & $<0.03$ & & 1.6 \\
\hline $21 / 05 / 2006$ & 18 & 3 & $<2$ & 38 & 0.25 & 4.4 & 0.10 & 9.33 & 0.10 & 10.4 & 0.08 & 4 & 5.3 \\
\hline $26 / 05 / 2006$ & 11.1 & 10 & $<2$ & 8 & 0.04 & 3.4 & 0.07 & 11 & 0.07 & 11 & $<0.03$ & & NA \\
\hline $29 / 05 / 2006$ & 14.6 & 7 & $<2$ & 18 & 0.14 & 6.7 & 0.10 & 12 & 0.10 & 14.4 & 0.08 & 7 & 4.5 \\
\hline $14 / 06 / 2006$ & 24.7 & 1 & 10 & 94 & 0.44 & 5.2 & 0.28 & 10.4 & 0.26 & 11.4 & 0.24 & 9.84 & 5.9 \\
\hline $03 / 08 / 2006$ & 12.9 & 4 & $<2$ & 30 & 0.09 & 10.2 & 0 & & 0 & & $<0.03$ & & 8.1 \\
\hline $04 / 08 / 2006$ & 17.6 & 5 & $<2$ & 36 & 0.11 & 9.6 & 0 & & 0 & & $<0.03$ & & 7.6 \\
\hline $05 / 08 / 2006$ & 8.2 & 2 & $<2$ & 30 & 0.29 & 8.9 & 0.05 & 7.25 & 0.05 & 6.3 & $<0.03$ & & 7.1 \\
\hline
\end{tabular}




\begin{tabular}{|c|c|c|c|c|c|c|c|c|c|c|c|c|c|}
\hline $14 / 08 / 2006$ & 22.5 & 6 & 2 & 29 & 0.16 & 8.9 & 0.08 & 11.1 & 0.08 & 11.75 & 0.09 & 1.66 & 1.7 \\
\hline $15 / 08 / 2006$ & 10 & 3 & $<0$ & 23 & 0.09 & 14 & 0.06 & 10 & 0.06 & 12.7 & $<0.03$ & & 11.2 \\
\hline $16 / 08 / 2006$ & 10.3 & 1.5 & $<2$ & 32 & 0.33 & 20.9 & 0.09 & 10.4 & 0.09 & 12.5 & 0.07 & 3.9 & 4.5 \\
\hline $19 / 08 / 2006$ & 7.9 & 0.33 & $<2$ & 43 & 0.12 & 2.5 & 0.08 & 13.25 & 0.07 & 14.66 & $<0.03$ & & 2 \\
\hline $21 / 08 / 2006$ & 23.4 & 4 & 2 & 37 & 0.37 & 9 & 0.17 & 14.33 & 0.13 & 15 & 0.11 & 8.75 & 3.9 \\
\hline $17 / 11 / 2006$ & 14.8 & 7 & $<2$ & 17 & NA & NA & 0.07 & 10.5 & 0.07 & 8 & $<0.03$ & & NA \\
\hline $19 / 11 / 2006$ & 8.4 & 5.5 & $<2$ & 7 & NA & NA & 0.05 & 17 & 0.05 & 21.9 & $<0.03$ & & NA \\
\hline $07 / 12 / 2006$ & 7 & 2.5 & $<2$ & 6 & 0.11 & 4.6 & 0.05 & 14.5 & 0.05 & 18.5 & $<0.03$ & & 3.7 \\
\hline $08 / 12 / 2006$ & 12 & 3 & $<2$ & 10 & 0.03 & 2.1 & 0.07 & 13.5 & 0.07 & 16.5 & $<0.03$ & & 1.6 \\
\hline $12 / 12 / 2006$ & 6.2 & 5 & $<2$ & 6 & 0.03 & 6.1 & 0.06 & NA & 0.06 & NA & 0.04 & NA & 4.9 \\
\hline $18 / 01 / 2007$ & 16 & 17.5 & $<2$ & 7 & 0.03 & 2.6 & 0.07 & 21.4 & 0.07 & 18.4 & $<0.03$ & & 2.1 \\
\hline 19/01/2007 & 13 & 6 & $<2$ & 11 & 0.12 & 4.1 & 0.10 & 17 & 0.10 & 18.4 & 0.08 & 4.5 & 3.3 \\
\hline $26 / 02 / 2007$ & 15.7 & 14.5 & $<2$ & 17 & 0.14 & 3.6 & 0.09 & 15.5 & 0.09 & 18.5 & 0.07 & 3.5 & 2.4 \\
\hline $28 / 02 / 2007$ & 10.2 & 7 & $<2$ & 12 & 0.09 & 4.5 & 0.06 & 9.5 & 0.06 & 11 & $<0.03$ & & 3.5 \\
\hline 07/03/2007 & 10.6 & 22 & $<2$ & 7 & 0.06 & 2.5 & 0.03 & 8 & 0.03 & 8.4 & $<0.03$ & & 2.0 \\
\hline $25 / 05 / 2007$ & 13.5 & 2 & $<2$ & 74 & 0.19 & 3.3 & 0.04 & 4.5 & 0.04 & 3.25 & $<0.03$ & & 2.7 \\
\hline $11 / 06 / 2007$ & 43 & 1 & 150 & 110 & 1.47 & 22.7 & 0.44 & 14 & 0.39 & 15.15 & 0.37 & 16.25 & 16.4 \\
\hline $18 / 06 / 2007$ & 5 & 0.33 & $<2$ & 19 & 0.10 & 19.6 & 0.04 & NA & 0.07 & 19 & 0.05 & 3 & 4.5 \\
\hline $25 / 06 / 2007$ & 10.8 & 10 & $<2$ & 41 & 0.05 & 0.8 & 0.03 & NA & 0.04 & 7.7 & $<0.03$ & & 0.6 \\
\hline 20/07/2007 & 14.5 & 6 & $<2$ & 30 & 0.06 & 1.2 & 0.07 & NA & 0.03 & 7 & $<0.03$ & & 0.9 \\
\hline $28 / 07 / 2007$ & 15.9 & 9.5 & $<2$ & 16 & 0.14 & 4.8 & 0.07 & 14 & 0.03 & 13 & 0.05 & 1.5 & 0.8 \\
\hline 02/08/2007 & 19.4 & 4 & 2 & 20 & 0.31 & 9.5 & 0.16 & 17 & 0.13 & 16.5 & 0.10 & 8 & 3.9 \\
\hline 09/08/2007 & 50 & 14 & 50 & 12 & 0.34 & 15.1 & 0.28 & 34 & 0.27 & 33 & 0.26 & 28.5 & 9.5 \\
\hline $21 / 08 / 2007$ & 20.8 & 17 & $<2$ & 34 & 0.24 & 6.9 & 0.11 & 19.5 & 0.11 & 20 & 0.09 & 8 & 2.6 \\
\hline
\end{tabular}

a Data for the period 2002-2004 are available from 'crest stage recorder' measurements. Such a recorder consists of a plastic tube with a length of water-sensitive tape which changes colour on contact with water.

A : Rainfall amount.

$\mathrm{D}$ : Duration of the event.

$\mathrm{T}$ : Return period according to Delbeke (2001).

$\mathrm{I}_{\mathrm{max}}$ : Maximum rainfall intensity in 5 minutes.

$\mathrm{Q}$ : Peak discharge.

RC : Runoff coefficient.

NA : Not available. 
Table 3. Summary of $t$-test results to detect significant differences in the flume (upstream of GWW) and at the outlet. SD $=$ standard deviation.

\begin{tabular}{|c|c|c|c|c|c|c|c|c|c|c|}
\hline \multirow[t]{2}{*}{ Parameter } & \multicolumn{2}{|c|}{ Peak discharge per ha } & \multicolumn{2}{|c|}{ Runoff coefficient } & \multicolumn{2}{|c|}{ Flow duration } & \multicolumn{2}{|c|}{ Lag time } & \multicolumn{2}{|c|}{ Sediment discharge } \\
\hline & Flume & Outlet & Flume & Outlet & Flume & Outlet & Flume & Outlet & Flume & Outlet \\
\hline Mean & 0.8 & 0.2 & 7.5 & 4.4 & 9.6 & 15.5 & 1.2 & 5 & 3.2 & 0.2 \\
\hline SD & 1.2 & 0.3 & 5.9 & 3.5 & 5 & 6 & 1.1 & 1.4 & 8 & 0.6 \\
\hline Observations & 30 & 30 & 30 & 30 & 15 & 15 & 15 & 15 & 10 & 10 \\
\hline$t$ stat & \multicolumn{2}{|c|}{2.4} & \multicolumn{2}{|c|}{2.5} & \multicolumn{2}{|c|}{-2.8} & \multicolumn{2}{|c|}{-8.1} & \multicolumn{2}{|c|}{1.9} \\
\hline $\mathrm{P}(\mathrm{T} \leq t)$ & \multicolumn{2}{|c|}{$<0.01$} & \multicolumn{2}{|c|}{$<0.05$} & \multicolumn{2}{|c|}{$<0.01$} & \multicolumn{2}{|c|}{$<0.0001$} & \multicolumn{2}{|c|}{$0.064(\mathrm{NS})$} \\
\hline
\end{tabular}

$\mathrm{NS}=$ not significant. 
Table 4. Muddy flood events requiring fire brigade interventions in Velm village between 1977-2002 and associated rainfall depth. Return periods after Delbeke (2001).

\begin{tabular}{llcc}
\hline Date & Daily rainfall $(\mathrm{mm})$ & Duration (hours) & Return period \\
\hline $20 / 07 / 1980$ & 38 & $<24$ & $>5$ \\
$10 / 08 / 1992$ & 44.5 & $<24$ & $>5$ \\
$08 / 06 / 1996$ & 21 & $<24$ & $>10$ \\
$13 / 08 / 1996$ & 47 & $<24$ & \\
$30 / 05 / 1999$ & NA & & \\
$08 / 05 / 2000$ & NA & $<24$ & \\
$03 / 06 / 2000$ & 18.2 & $<24$ & $>100$ \\
$14 / 07 / 2000$ & 13.6 & $<24$ & $>5$ \\
$25 / 07 / 2000$ & 66.5 & $<24$ & 5 \\
$29 / 07 / 2000$ & 23.2 & $<24$ & 10 \\
$02 / 08 / 2001$ & 40 & 1 & 5 \\
$09 / 05 / 2002$ & 20 & 1 & 20 \\
$20 / 06 / 2002$ & 25 & 8 & 100 \\
$20 / 07 / 2002$ & 30 & 0.5 & 200 \\
$03 / 08 / 2002$ & 25 & 3 & \\
$20 / 08 / 2002$ & 50 & 1 & \\
$27 / 08 / 2002$ & 70 & & \\
& & & \\
\hline
\end{tabular}


Table 5. Results of soil loss measurements in the San Dimas flume and sediment concentrations in the outflow of the dams. $\mathrm{N}$ is the number of water samples taken in the flume. Two water samples have systematically been taken behind the dams.

\begin{tabular}{|c|c|c|c|c|c|c|}
\hline \multirow[b]{2}{*}{$\begin{array}{l}\text { Date } \\
(\mathrm{d} / \mathrm{m} / \mathrm{y})\end{array}$} & \multicolumn{3}{|c|}{ San Dimas Flume } & \multirow{2}{*}{$\begin{array}{l}\text { Dam } 1 \\
\begin{array}{l}\text { Sediment } \\
\text { conc. }\left(\mathrm{g} \mathrm{l}^{-1}\right)\end{array}\end{array}$} & \multirow{2}{*}{$\begin{array}{l}\text { Dam } 2 \\
\text { Sediment } \\
\text { conc. }\left(\mathrm{g} \mathrm{l}^{-1}\right)\end{array}$} & \multirow{2}{*}{$\begin{array}{l}\text { Dam } 3 \\
\text { Sediment } \\
\text { conc. }\left(\mathrm{g} \mathrm{l}^{-1}\right)\end{array}$} \\
\hline & $\begin{array}{l}\text { Soil loss } \\
(\mathrm{T})\end{array}$ & $\begin{array}{l}\text { Mean sediment } \\
\text { conc. }\left(\mathrm{g} \mathrm{l}^{-1}\right)\end{array}$ & $\mathrm{N}$ & & & \\
\hline $26 / 05 / 2006$ & 1 & 0.9 & 2 & 0.4 & 0.2 & NA \\
\hline 29/05/2006 & 20 & 10 & 10 & 0.2 & 0.1 & NA \\
\hline $14 / 06 / 2006$ & 120 & 30.9 & 24 & 1.7 & 1.3 & 1.9 \\
\hline $21 / 08 / 2006$ & 19 & 3.8 & 24 & 1.1 & 1.1 & 0.6 \\
\hline 08/12/2006 & 5 & 0.7 & 2 & 0.4 & 0.4 & 0.3 \\
\hline $26 / 02 / 2007$ & 13 & 3.2 & 2 & 0.3 & 0.3 & 0.3 \\
\hline $28 / 02 / 2007$ & 4 & 1.2 & 2 & 0.3 & NA & NA \\
\hline 07/03/2007 & 2 & 1.1 & 2 & 0.9 & 0.3 & NA \\
\hline $25 / 05 / 2007$ & 2 & 2.1 & 2 & 0.7 & NA & NA \\
\hline $11 / 06 / 2007$ & 117 & 5 & 24 & 1.6 & 1.9 & 2.2 \\
\hline $18 / 06 / 2007$ & 10 & 4.4 & 4 & 0.3 & 0.2 & NA \\
\hline 02/08/2007 & 5 & 1.2 & 2 & 0.6 & 0.5 & 0.5 \\
\hline 09/08/2007 & 16 & 0.9 & 3 & 0.9 & 0.2 & 0.3 \\
\hline
\end{tabular}

